DOI: https://doi.org/10.24127/ajpm.v9i1.2668

\title{
PROFIL BERPIKIR KRITIS CALON GURU MATEMATIKA DALAM PEMBUKTIAN TEOREMA GEOMETRI
}

\author{
Siti Lailiyah \\ Pendidikan Matematika, UIN Sunan Ampel Surabaya, Indonesia \\ E-mail: $\quad$ lailiyah@uinsby.ac.id
}

Received 31 January 2020; Received in revised form 25 March 2020; Accepted 29 March 2020

\begin{abstract}
Abstrak
Tujuan penelitian ini yaitu mendeskripsikan berpikir kritis mahasiswa calon guru matematika dalam membuktikan teorema geometri. Berpikir kritis merupakan salah satu keterampilan abad 21 terpenting yang dibutuhkan dunia kerja atau dunia industri, salah satunya adalah berpikir kritis. Jenis penelitian ini adalah penelitian deskripstif kualitatif dengan tiga subjek penelitian mahasiswa pendidikan matematika UIN Sunan Ampel Surabaya. Instrumen penelitian ini terdiri dari tes tulis dan wawancara yang selanjutnya data dikelompokkan dan dianalisis sesuai dengan indikator berpikir kritis. Berdasarkan hasil analisis data, didapatkan: (1) dua subjek dapat menuliskan dan menyebutkan apa yang dibuktikan pada masalah tersebut namun sebagian benar dan sebagian salah, hanya satu subjek yang menuliskan dengan benar dan lengkap, (2) semua subjek menggambarkan segitiga dengan benar dan simbol-simbol matematika yang ditulis tepat, (3) semua subjek dapat membuktikan teorema dengan cara benar dan sistematis, dan (4) dua subjek melakukan pengecekan kembali namun pengecekannya tidak lengkap dan tidak sistematis, sedangkan satu subjek tidak melakukan pengecekan pembuktian teorema. Jadi dapat disimpulkan bahwa berpikir kritis mahasiswa calon guru matematika pada penelitian ini dalam membuktikan teorema geometri termasuk kategori sangat baik.
\end{abstract}

Kata kunci: Berpikir kritis; pembuktian; teorema geometri.

\begin{abstract}
The purpose of this study is to describe the critical thinking of prospective mathematics teacher students in proving the geometry theorem. Critical thinking is one of the most important 21st-century skills needed by the world of work or industry, one of which is critical thinking. This type of research is a qualitative descriptive study with three research subjects mathematics education students of UIN Sunan Ampel Surabaya. The instrument of this study consisted of written tests and interviews in which the data were grouped and analyzed according to indicators of critical thinking. Based on the results of data analysis, it is found: (1) two subjects can write down and mention what is proven on the problem but some are correct and some are wrong, only one subject writes correctly and completely, (2) all subjects draw triangles correctly and mathematical symbols are written correctly, (3) all subjects can prove theorems correctly and systematically, and (4) two subjects re-check but the checks are incomplete and not systematic, while one subject does not verify the theorem. So it can be concluded that the critical thinking of prospective mathematics teacher students in this study in proving the geometry theorem is very good.
\end{abstract}

Keywords: Critical thinking; geometry theorem; proof.

\section{PENDAHULUAN}

Guru yang profesional adalah guru yang mampu menjadi pembelajar di sepanjang karir untuk meningkatkan keefektifan proses pembelajaran (Andriani, 2012). Selain mempersiapkan diri, seorang guru juga harus menyiapkan peserta didiknya untuk menghadapi era abad 21. Oleh karena itu, seorang guru harus memiliki berbagai macam keterampilan untuk menghadapi abad 21 sehingga dapat mempersiapkan peserta didik menguasai berbagai keterampilan tersebut agar menjadi pribadi yang sukses (Tican \& Deniz, 2018). 
DOI: https://doi.org/10.24127/ajpm.v9i1.2668

\section{Common Core State Standars} (CCSS) mengintegrasikan kerangka pendidikan abad 21 yang disiapkan oleh The Partnership for 21st Century Skills (P21). The Partnership for 21st Century Skills menganjurkan integrasi pengetahuan akademis, pemikiran kritis, dan keterampilan sosial dalam pengajaran dan pembelajaran untuk membantu peserta didik menguasai kemampuan multi-dimensi yang diperlukan pada abad ke-21 (Alismail \& McGuire, 2015). Terdapat tujuh keterampilan abad 21 yang diperlukan dalam karir, kuliah dan masyarakat yaitu (1) berpikir kritis dan pemecahan masalah, (2) kolaborasi lintas jaringan dan kepemimpinan, (3) ketangkasan dan adaptasi, (4) inisiatif dan kewirausahaan, (5) komunikasi lisan dan tulis yang efektif, (6) mengakses dan menganalisis informasi, serta (7) rasa ingin tahu dan daya khayal (Hidayah, Salim, \& McGuire, 2017).

Salah satu urutan terpenting keterampilan abad 21 yang dibutuhkan dalam dunia kerja atau dunia industri yaitu berpikir kritis dalam pemecahan masalah matematis yang memiliki persentase $96,21 \%$, sedangkan keterampilan yang lain memiliki persentase di bawah keterampilan berpikir kritis (Wijaya, Sudjimat, \& Nyoto, 2016). Berpikir kritis juga berperan penting dalam proses pendidikan agar peserta didik mampu mengambil suatu keputusan (Karakoç, 2016). Berdasarkan hasil penelitian tersebut maka dapat disimpulkan bahwa berpikir kritis sangat penting di abad 21.

Berpikir kritis merupakan salah satu komponen dari berpikir tingkat tinggi, dimana ditandai dengan kemampuan menganalisis masalah, menentukan kecukupan data untuk menyelesaikan masalah, menganalisis situasi, dan menentukan kevalidan suatu data (Lailiyah, dkk, 2015). "Berpikir kritis adalah proses yang berpusat atau bermuara pada pembuatan dan penarikan kesimpulan atau keputusan yang logis tentang tindakan apa yang harus dilakukan dan apa yang harus dipercaya atau diyakini" (Ikhsan, Munzir, \& Fitria, 2017, hal. 235).

Berpikir kritis harus dilatihkan dan dikembangkan pada pembelajaran. Hal ini dapat memberi kesempatan kepada peserta didik agar dapat memahami dan bertanggungjawab atas pembelajaran tersebut (Murawski, 2014). Cara melatihkan dan mengembangkan berpikir kritis pada pembelajaran dengan melibatkan setiap peserta didik pada cara berpikir tertentu termasuk metakognisi, mengetahui bagaimana cara membuat argumen, pengambilan keputusan, berpikir kritis, inovatif, pembuktian dan pemecahan masalah (Griffin \& Care, 2015). Peserta didik yang mampu mengidentifikasi fakta dalam masalah, mengetahui pengetahuan yang tepat untuk membuktikan teorema dengan akurat maka peserta didik tersebut tergolong level berpikir sangat kritis (Rasiman, 2015).

Beberapa penelitian tentang berpikir kritis telah banyak dilakukan ( (Khamidah \& Suherman, 2016); (Ikhsan, Munzir, \& Fitria, 2017); (Prayitno, 2018); (Febrilia, Juliangkary, \& Korida, 2019); (Maharani, Rasiman, \& Rahmawati, 2019); (Basri \& Purwanto, 2019)). Penelitian- penelitian yang diteliti selama ini hanya pada proses berpikir kritis dalam penyelesaian atau pemecahan masalah matematika bukan pada pembuktian. Penelitian tentang berpikir kritis dalam membuktikan suatu teorema belum banyak diteliti, padahal konsep-konsep dalam matematika yang abstrak tersusun berjenjang dan berurutan mulai 
DOI: https://doi.org/10.24127/ajpm.v9i1.2668

tingkat dasar, menengah sampai perguruan tinggi diperlukan pembuktian-pembuktian khusus (Suandi, 2017). Hal ini juga sesuai dengan indikator berpikir kritis yaitu memahami masalah matematika yang diterapkan melalui analisis dan sintesis pembuktian dan pemecahan masalah matematika (Partnership21, 2011).

Pembuktian matematis merupakan salah satu cara yang paling tepat dalam menyakini kebenaran dari suatu hal (Santosa, 2013). Pada pembuktian matematis dalam hal ini sebuah teorema, peserta didik dituntut berpikir secara runtut, detail dan menghubungkan apa yang diketahui dengan apa yang ditanyakan pada suatu masalah (Ikhsan, Munzir, \& Fitria, 2017). Pada proses pembuktian juga membutuhkan kemampuan kognitif tingkat tinggi (seperti berpikir kritis), sehingga menghasilkan argumentasi logis dan mempresentasikannya secara efektif (Yerizon, 2011).

Pentingnya keterampilan berpikir kritis pada calon guru dikarenakan menjadi salah satu penunjang keberhasilan di abad 21 (Bustami, Suarsini, \& Ibrohim, 2019). Bustami, Suarsini \& Ibrohim (2019) juga menyatakan bahwa keterampilan berpikir kritis calon guru harus dilatih secara terus-menerus agar terampil dalam menyusun rencana secara sistematis serta terampil dalam memecahkan masalah dan membuktikan teorema. Beberapa tanda bahwa seorang peserta didik telah berpikir kritis dalam membuktikan teorema matematis yaitu mampu menganalisis masalah dengan tepat, mampu menentukan kecukupan data dalam menyelesaikan suatu masalah /membuktikan teorema dengan tepat, mampu menganalisis situasi dengan baik, dan mampu menentukan kevalidan suatu kesimpulan dengan tepat (Lailiyah, dkk, 2015). Berdasarkan latar belakang tersebut, penelitian ini memiliki tujuan mendeskripsikan berpikir kritis mahasiswa calon guru matematika dalam membuktikan teorema geometri.

\section{METODE PENELITIAN}

Penelitian ini menggunakan pendekatan kualitatif. Penelitian ini bertujuan mendeskripsikan kemampuan berpikir kritis mahasiswa calon guru dalam membuktikan teorema geometri. Teknik pengambilan subjek pada penelitian ini menggunakan purposive sampling. Oleh karena itu, subjek dalam penelitian ini yaitu 3 calon guru Pendidikan Matematika Fakultas Tarbiyah dan Keguruan UIN Sunan Ampel Surabaya yang mengikuti program PPL (Praktik Pengalaman Lapangan) Tahun Akademik 2019 di MA Hasyim Asya'ari Sukodono Sidoarjo. Alasan pemilihan 3 subjek tersebut dikarenakan dari 9 mahasiswa yang melakukan PPL di MA Hasyim Asyari Sukodono Sidoarjo hanya ada 3 calon guru prodi pendidikan matematika, sedangkan mahasiswa yang lainnya bukan berasal dari prodi pendidikan matematika. Adapun subjek penelitian ini disajikan pada Tabel 1 .

Tabel 1. Subjek Penelitian

\begin{tabular}{cc}
\hline Inisial Subjek & Kode \\
\hline EDRU & $\mathrm{S}_{1}$ \\
MAP & $\mathrm{S}_{2}$ \\
NLS & $\mathrm{S}_{3}$ \\
\hline
\end{tabular}

Instrumen dalam penelitian ini adalah tes berpikir kritis dan pedoman wawancara. Tes berpikir kritis dalam penelitian ini adalah pembuktian satu teorema geometri tentang jumlah ketiga sudut pada segitiga. Alasan pemilihan 
DOI: https://doi.org/10.24127/ajpm.v9i1.2668

teorema tersebut adalah karena materi pada teorema ini sudah dipelajari sejak Kelas VII sampai tingkat perguruan tinggi. Sedangkan pedoman wawancara bertujuan untuk mendalami proses berpikir kritis mahasiswa saat mengerjakan tes berpikir kritis. Proses triangulasi yang digunakan adalah triangulasi sumber, dimana hasil dari ketiga subjek tersebut dicari kesamaan dan perbedaannya. Analisis data berpikir kritis menggunakan indikator berpikir kritis menurut P21 (Partnership21, 2011), seperti pada Tabel 2.

Tabel 2. Pedoman penskoran berpikir kritis dalam pembuktian teorema segitiga.

\begin{tabular}{llll}
\hline \multicolumn{2}{c}{$\begin{array}{c}\text { Indikator } \\
\text { Berpikir Kritis }\end{array}$} & \multicolumn{1}{c}{ Aspek yang Dinilai } & Skor \\
\hline 1) & Mencari & Tidak menuliskan dan atau menyebutkan apa yang diketahui dan apa & 0 \\
struktur logis & yang dibuktikan pada masalah tersebut. & \\
dalam & Menuliskan dan atau menyebutkan apa yang diketahui dan apa yang & 1 \\
mengatasi & dibuktikan pada masalah tersebut namun salah. & \\
tantangan & Menuliskan dan atau menyebutkan apa yang diketahui dan apa yang & 2 \\
matematika. & dibuktikan pada masalah tersebut namun sebagian benar dan sebagian & \\
& salah. & \\
& $\begin{array}{l}\text { Menuliskan dan atau menyebutkan apa yang diketahui dan apa yang } \\
\text { dibuktikan pada masalah tersebut dengan benar namun kurang lengkap. }\end{array}$ & \\
& $\begin{array}{l}\text { Menuliskan dan atau menyebutkan apa yang diketahui dan apa yang } \\
\text { dibuktikan pada masalah tersebut dengan benar dan lengkap. }\end{array}$ &
\end{tabular}

2) Menggambar segitiga dengan benar dan simbolsimbol matematika yang ditulis sudah tepat semua.

3) Memahami masalah matematika yang diterapkan melalui analisis dan sintesis pembuktian

Tidak menggambar segitiga terhadap informasi yang diperoleh dari soal. Menggambar segitiga dengan benar namun belum ada simbol-simbol 1 matematika dan nama segitiga yang digambar.

Menggambar segitiga dengan benar dan sudah terdapat simbol-simbol 2 matematika akan tetapi terdapat banyak simbol yang belum tepat. $\begin{array}{lll}\text { Menggambar segitiga dengan benar dan sudah terdapat simbol-simbol } & 3\end{array}$ matematika akan tetapi terdapat sedikit simbol yang belum tepat. Menggambar segitiga dengan benar dan simbol-simbol matematika yang 4 ditulis sudah tepat semua.

Tidak membuktikan teorema pada masalah atau tidak menjawab soal. $\quad 0$ Membuktikan teorema pada masalah dengan kurang sistematis 1 (menyebutkan apa yang diketahui saja, atau yang ditanya saja atau jawaban saja atau hanya menyebutkan beberapa yang diketahui dan beberapa yang ditanya) dan melakukan kesalahan dalam proses penyelesaian.

Membuktikan teorema pada masalah dengan sistematis (menyebutkan apa yang diketahui, ditanya dan jawaban), namun melakukan kesalahan dalam proses penyelesaian sehingga seluruh jawaban salah. Membuktikan teorema pada masalah dengan cara yang benar, 3 sistematis (menyebutkan apa yang diketahui, ditanya dan jawaban), namun terdapat beberapa kesalahan dalam melakukan pembuktian atau belum selesai saat mengerjakan sehingga jawaban salah.

Membuktikan teorema pada masalah dengan cara yang benar, 4 sistematis (menuliskan apa yang diketahui, ditanya dan jawaban) serta jawabannya benar. 
DOI: https://doi.org/10.24127/ajpm.v9i1.2668

\begin{tabular}{|c|c|c|}
\hline $\begin{array}{c}\text { Indikator } \\
\text { Berpikir Kritis }\end{array}$ & Aspek yang Dinilai & Skor \\
\hline 4) Menganalisis & Tidak membuktikan teorema dan tidak melakukan pengecekan jawaban. & 0 \\
\hline bagaimana & Membuktikan teorema dan tidak melakukan pengecekan kembali. & 1 \\
\hline $\begin{array}{l}\text { seluruh bagian } \\
\text { dalam sistem } \\
\text { matematika } \\
\text { saling }\end{array}$ & $\begin{array}{l}\text { Membuktikan teorema dan melakukan pengecekan kembali sebagai } \\
\text { sistem matematika yang saling berinteraksi namun pengecekannya tidak } \\
\text { lengkap dan tidak sistematis atau masih banyak yang salah dalam } \\
\text { pengecekan jawaban. }\end{array}$ & 2 \\
\hline & $\begin{array}{l}\text { Membuktikan teorema dan melakukan pengecekan kembali sebagai } \\
\text { sistem matematika yang saling berinteraksi namun masih ada sedikit } \\
\text { yang salah dalam pengecekan jawaban. }\end{array}$ & 3 \\
\hline & $\begin{array}{l}\text { Membuktikan teorema dan melakukan pengecekan kembali dengan } \\
\text { benar dan tidak terdapat kesalahan saat pengecekan jawaban. }\end{array}$ & 4 \\
\hline
\end{tabular}

Setelah data jawaban tertulis disajikan, langkah selanjutnya yaitu melihat kekonsistenan data profil berpikir kritis calon guru Pendidikan Matematika dengan mensinkronkan data wawancara menggunakan triangulasi sumber. Selanjutnya dibuat kesimpulan dengan menjumlahkan skor pada masing-masing aspek penilaian yang selanjutnya dikategorikan pada beberapa kategori yaitu kurang, cukup, baik, dan sangat baik (Tabel 3).

Tabel 3. Kategori berpikir kritis dalam pembuktian teorema segitiga.

\begin{tabular}{cc}
\hline Total Skor & Kategori \\
\hline $0 \leq x<4$ & Kurang \\
$4 \leq x<8$ & Cukup \\
$8 \leq x<12$ & Baik \\
$12 \leq x \leq 16$ & Sangat Baik \\
\hline
\end{tabular}

Analisis data wawancara menggunakan beberapa tahapan, antara lain: (1) mereduksi data, (2) menyusun data-data yang dikategorisasikan dengan membuat coding, menetapkan label untuk masing-masing kode, (4) pemaparan data, dan (5) penarikan kesimpulan. Adapun koding transkrip wawancara menggunakan simbol $P_{a . b . c}$ dan $S_{a . b . c}$, dengan $P=$ peneliti, $S=$ subjek, $a=$ urutan subjek, dan $b=$ urutan pertanyaan/jawaban.

\section{HASIL DAN PEMBAHASAN}

\section{Berpikir Kritis Subjek $S_{1}$}

a. Mencari struktur logis dalam mengatasi tantangan matematika

Apabila melihat jawaban tertulis

$S_{1}$, tampak bahwa $S_{1}$ tidak menuliskan apa yang diketahui dan apa yang akan dibuktikan. Akan tetapi pada hasil wawancara $S_{1.1}$, dan $S_{1.2}$ tampak bahwa $\mathrm{S}_{1}$ menjelaskan informasi yang ada pada masalah tersebut dengan menyebutkan langkah pertama yang harus dilakukan dalam pembuktian masalah tersebut adalah dengan menggambar sebuah segitiga ABC. Selanjutnya $\mathrm{S}_{1}$ menyebutkan apa yang dibuktikan pada masalah tersebut dengan tepat. Jadi berdasarkan pedoman penskoran tes berpikir kritis maka dapat disimpulkan bahwa skor yang diperoleh $S_{1}$ untuk indikator pertama yaitu mencari struktur logis dalam mengatasi matematika adalah menyebutkan apa yang diketahui dan apa yang ditanyakan dari soal namun sebagian benar dan sebagian salah dengan perolehan skor 2 (dua). Berikut Transkrip wawancara subjek $\mathrm{S}_{1}$ ketika menyelesaikan soal:

$S_{1.1}$ : Saya mencari cari referensi bagaimana segitiga itu bisa diketahui jumlah sudutnya 180 derajat. Langkah-langkahnya yang pertama saya buat segitiga sembarang bu, saya bikin $\mathrm{ABC}$, terus dari salah satu titik ini, boleh di A, atau B atau C itu itu saya 
DOI: https://doi.org/10.24127/ajpm.v9i1.2668

perpanjang... saya pakai di titik C saya perpanjang nanti saya beri nama titik D jadinya seperti ini (sambil menunjuk gambar pada lembar kerjanya) perpanjangan dari $\mathrm{C}$, terus perpanjangan di titik $\mathrm{C}$ di garis AC jadinya nanti AD... terus saya yang langkah yang ketiga itu saya buat garis yang sejajar dengan garis $\mathrm{AB}$ melalui titik $\mathrm{C}$ jadi terus saya nama, saya beri nama garis EC seperti ini.

$S_{1.2}$ : Saya harus membuktikan kalo segitiga ABC, jumlah seluruh sudutnya itu (sambil menunjukkan masing-masing sudut pada segitiga tersebut) 180 derajat.

\section{b. Menggambar segitiga dengan benar dan simbol-simbol matematika yang ditulis sudah tepat semua.}

Pada Gambar 1 terlihat bahwa $\mathrm{S}_{1}$ menggambarkan segitiga dengan benar dan simbol-simbol matematika yang ditulis sudah tepat semua. Jadi berdasarkan pedoman penskoran tes berpikir kritis untuk indikator kedua yaitu peserta didik mampu menggambar segitiga dengan benar dan simbolsimbol matematika yang ditulis dengan tepat memperoleh skor 4 (empat). Adapun jawaban tertulis $S_{1}$ untuk indikator kedua disajikan pada Gambar 1 .

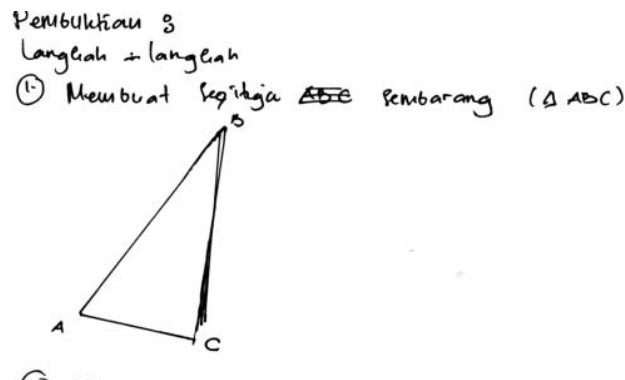

Membuat perpanjangan garis Dari thle $C$. dan beri nania titile $D$

Gambar 1. Jawaban Tertulis $S_{1}$ dalam menggambar segitiga.

\section{c. Memahami masalah matematika yang diterapkan melalui analisis dan sintesis pembuktian}

Adapun jawaban tertulis $S_{1}$ untuk indikator ketiga disajikan pada Gambar
2. Pada Gambar 2 dan transkrip wawancara $S_{1.3}$ terlihat bahwa $S_{1}$ membuktikan teorema segitiga tersebut dengan memperpanjang salah satu sisi pada segitiga ABC tersebut (sisi AC) lalu membuat garis lain yang sejajar dengan garis $\mathrm{AB}$ melalui titik $\mathrm{C}$. Langkah-langkah pembuktian yang dilakukan $\mathrm{S}_{1}$ sistematis dan pembuktian teoremanya tepat. Jadi berdasarkan pedoman penskoran tes berpikir kritis untuk indikator ketiga yaitu peserta didik mampu memahami masalah matematika yang diterapkan melalui analisis dan sintesis pembuktian matematika adalah mampu membuktikan teorema pada masalah dengan cara yang benar, sistematis dan jawabannya tepat dengan memperoleh skor 4 (empat).

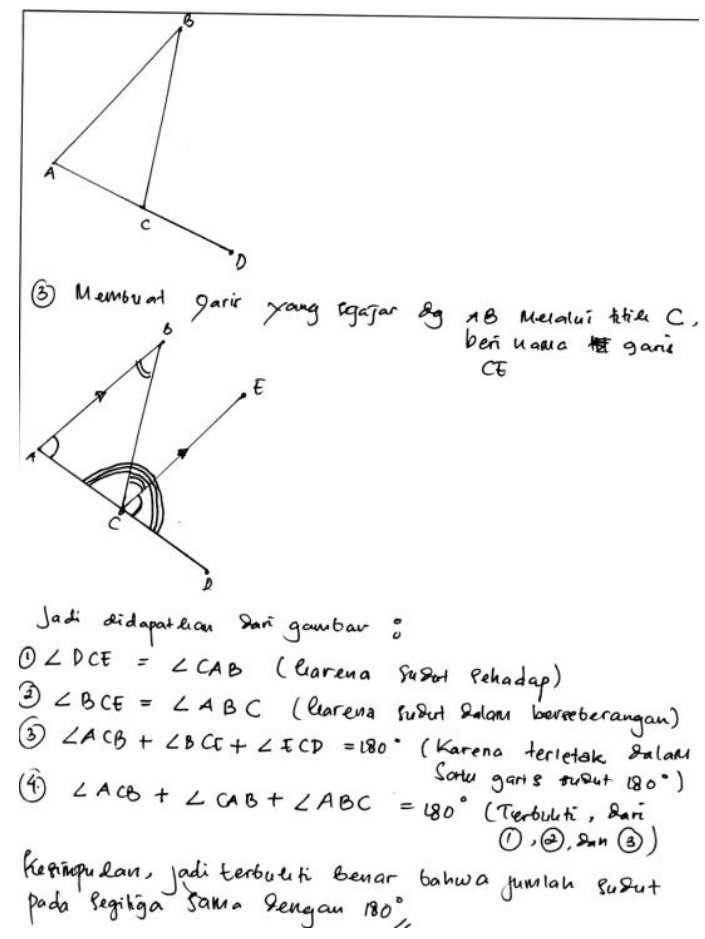

Gambar 2. Jawaban tertulis $S_{1}$ dalam membuktikan teorema.

Adapun transkrip wawancara $\mathrm{S}_{1}$ untuk indikator ketiga sebagai berikut:

$S_{1.3}$ : Ya bu, saya formulasikan seperti ini (sambil menunjuk jawaban pada halaman 
pertamanya), jadi dari dari gambar ini saya peroleh yang pertama itu sudut DCE. DCE itu sama dengan sudut $\mathrm{CAB}$ itu karena dua sudut ini adalah sudut sehadap, itu kan kalo ibu dulu menjelaskan dikasih alasannya apa, nanti saya beri nomor satu. Terus yang kedua, sudut BCE. BCE itu sama dengan sudut ABC. ABC (sambil menunjuk gambar sudutnya pada segitiga tersebut). Dikarenakan sudut dalam berseberangan, saya kasih tanda seperti ini.. saya beri nomor dua. Nomor tiga itu sudut ACB ditambah BCE ditambah ECD itu kan kan terletak di satu garis yaitu $A D$, karena terletak di satu garis maka satu garisnya ini sebesar 180 derajat. Jadi jumlah ketiga sudut yang tadi itu dijumlah 180 derajat.

\section{d. Menganalisis bagaimana seluruh bagian dalam sistem matematika saling berinteraksi}

Pada jawaban tertulis $S_{1}$ tampak bahwa $S_{1}$ tidak melakukan pengecekan kembali. Akan tetapi pada hasil wawancara $S_{1.17}$ dan $S_{1.18}$ tampak bahwa $S_{1}$ menjelaskan cara yang dilakukan pada pengecekan pembuktian adalah dengan melalui gambar, ketika gambarnya cocok maka pembuktiannya tepat. Jadi berdasarkan pedoman penskoran tes berpikir kritis untuk indikator keempat yaitu peserta didik mampu menganalisis bagaimana seluruh bagian dalam sistem matematika saling berinteraksi adalah membuktikan teorema dan melakukan pengecekan kembali sebagai sistem matematika yang saling berinteraksi namun pengecekannya tidak lengkap dan tidak sistematis dengan perolehan skor 2 (dua). Adapun transkrip wawancara untuk indikator keempat sebagai berikut:

$S_{1.17}$ : Saya langsung melihat saja bu di gambar... oo iya betul ini (sambil menunjuk segitiganya) terletak 180 derajat.

$P_{1.18}$ : Jadi pengecekannya melalui gambar itu tadi, ketika gambarnya sudah cocok maka terbukti?

$S_{1.18}$ : Iya bu
Berdasarkan deskripsi dan analisis data di atas, dapat disimpulkan skor berpikir kritis $S_{1}$ seperti pada Tabel 4 .

Tabel 4. Skor kemampuan berpikir kritis $S_{1}$.

\begin{tabular}{lll}
\hline No & \multicolumn{3}{c}{$\begin{array}{c}\text { Aspek Penilaian } \\
\text { Berpikir Kritis }\end{array}$} & Skor \\
\hline 1. & $\begin{array}{l}\text { Menuliskan dan atau } \\
\text { menyebutkan apa yang }\end{array}$ & 2 \\
dibuktikan pada masalah & \\
tersebut dengan tepat & \\
2. & $\begin{array}{l}\text { Menggambar segitiga dengan } \\
\text { benar dan simbol-simbol }\end{array}$ & 4 \\
matematika yang ditulis & \\
sudah tepat semua & \\
3embuktikan teorema pada & 4 \\
masalah dengan cara yang & \\
benar, sistematis \\
(menuliskan apa yang \\
diketahui, ditanya dan \\
jawaban) serta jawabannya \\
benar $\begin{array}{l}\text { Membuktikan teorema dan } \\
\text { melakukan pengecekan }\end{array}$ \\
kembali sebagai sistem \\
matematika yang saling \\
berinteraksi namun masih \\
ada sedikit yang salah dalam \\
pengecekan jawaban
\end{tabular}

Berdasarkan pada Tabel 4 diperoleh bahwa total skor pada aspek penilaian berpikir kritis sebesar 12. Skor total ini jika dikategorikan sesuai dengan Tabel 3 maka termasuk kategori "sangat baik". Jadi dapat disimpulkan bahwa berpikir kritis $S_{1}$ termasuk kategori sangat baik.

\section{Berpikir Kritis Subjek $S_{2}$}

a. Mencari struktur logis dalam mengatasi tantangan matematika

Apabila melihat jawaban tertulis $\mathrm{S}_{2}$ tampak bahwa $\mathrm{S}_{2}$ tidak menuliskan apa yang diketahui dan apa yang ditanyakan/apa yang akan dibuktikan. Akan tetapi pada hasil wawancara $S_{2.1}$ 
sampai $S_{2.4}, \mathrm{~S}_{2}$ hanya menyebutkan apa yang akan dibuktikan yaitu jumlah dalam sudut segitiga itu $180^{\circ} . \mathrm{S}_{2}$ tidak bisa menyebutkan informasi atau apa yang diketahui pada masalah tersebut dengan tepat. Jadi berdasarkan pedoman penskoran tes berpikir kritis dapat disimpulkan bahwa skor yang diperoleh $\mathrm{S}_{2}$ untuk indikator pertama yaitu mencari struktur logis dalam mengatasi matematika adalah menyebutkan apa yang diketahui dan apa yang ditanyakan dari soal namun sebagian benar dan sebagian salah dengan perolehan skor 2 (dua). Adapun transkrip wawancara $S_{2}$ sebagai berikut:

$\mathrm{S}_{2.1}$ : Informasi yang saya peroleh setelah saya membaca soal disini adalah saya disuruh membuktikan jumlah dari ketiga sudut dalam segitiga itu.

$\mathrm{P}_{2.2}$ : Informasi apa yang diperoleh bukan apa yang ditanyakan?

$\mathrm{S}_{2.2}$ : Jumlah sudut segitiganya sama dengan $180^{\circ}$.

$\mathrm{P}_{2.3}$ : Oke pertanyaan kedua, apa yang ditanyakan pada soal tersebut, bedakan dengan informasi dan apa yang ditanyakan?

$\mathrm{S}_{2.3}$ : Yang ditanyakan adalah, kita disuruh membuktikan apakah benar jumlah dalam sudut segitiga itu... sudut segitiga itu $180^{\circ}$.

$\mathrm{P}_{2.4}$ : Berarti informasinya yang diketahui?

$\mathrm{S}_{2.4}$ : (Berpikir lama) jumlah sudutnya $180^{\circ}$.

\section{b. Menggambar segitiga dengan benar dan simbol-simbol matematika yang ditulis sudah tepat semua.}

Pada Gambar 3 dan transkrip wawancara $S_{2.7}$ terlihat bahwa $\mathrm{S}_{2}$ menggambarkan segitiga $\mathrm{ABC}$ dengan benar dan simbol-simbol matematika yang ditulis sudah tepat semua. Jadi berdasarkan pedoman penskoran tes berpikir kritis untuk indikator kedua yaitu peserta didik mampu mengidentifikasi dan mengajukan pertanyaan penting tentang matematika dan terlibat dalam menganalisis jawabannya masingmasing adalah mampu menggambarkan segitiga dengan simbol-simbol matematikanya dengan tepat yang memperoleh skor 4 (empat). Adapun transkrip wawancara untuk indikator kedua dan ketiga sebagai berikut:

$S_{2.7}$ : Ya.. akan tetapi tidak semuanya... Yang pertama ada langkah-langkah pembuktiannya, saya menggambar segitiga sembarang $\mathrm{ABC}$, gambarnya seperti ini (sambil menunjuk gambar segitiga ABC yang sudah digambar pada lembar jawaban)... Kemudian langkah kedua pada sisi $\mathrm{AB}$, perpanjang ruas garis $\mathrm{AB}$ tersebut, jadi pada sisi $A B$ nya saya perpanjang sehingga terbentuk gambar seperti ini (sambil menunjuk garis perpanjang garis $A B)$, dan hasil perpanjangan ini saya beri satu titik yaitu B aksen (B'). (membalik lembar jawaban selanjutnya). Kemudian langkah yang ketiga buat garis yang sejajar dengan AC dan melalui titik $\mathrm{B}$ dan beri nama titik $\mathrm{C}$ aksen ( $\mathrm{C}^{\prime}$ ) di garis sejajar tersebut, gambarnya seperti ini (sambil menunjuk gambar garis yang sejajar dengan $A C$ ). Kemudian langkah keempat, perhatikan sudut di tiap titik ehh tiap titik sudut segitiga $\mathrm{ABC}$, dari gambar tersebut diperoleh informasi sudut $\mathrm{CAB}$ sama dengan sudut $\mathrm{C}^{\prime} \mathrm{BB}$ ' karena sehadap. Kemudian sudut ACB sama dengan sudut CBC' karena berseberangan dalam. Kemudian sudut ABB' besarnya adalah 180 derajat karena sudut berpelurus. Kemudian sudut $\mathrm{ABB}$ ' ini terbentuk dari sudut $\mathrm{ABC}$ ditambah dengan sudut $\mathrm{CBC}$ ' ditambah dengan sudut C'BB', sedangkan dari informasi sebelumnya sudut $\mathrm{ABC}$ ditambah sudut $\mathrm{CBC}$ ' sama dengan sudut CAB... maaf sudut $\mathrm{ACB}$ kemudian sudut C'BB' sama dengan sudut $\mathrm{CAB}$, kemudian kita jumlah hasilnya adalah 180 derajat. Itulah pembuktian yang saya lakukan terbukti bahwa jumlah sudut dalam segitiga adalah 180 derajat.

Sedangkan jawaban tertulis $\mathrm{S}_{2}$ dalam menggambar segitiga dengan benar disajikan pada Gambar 3. 


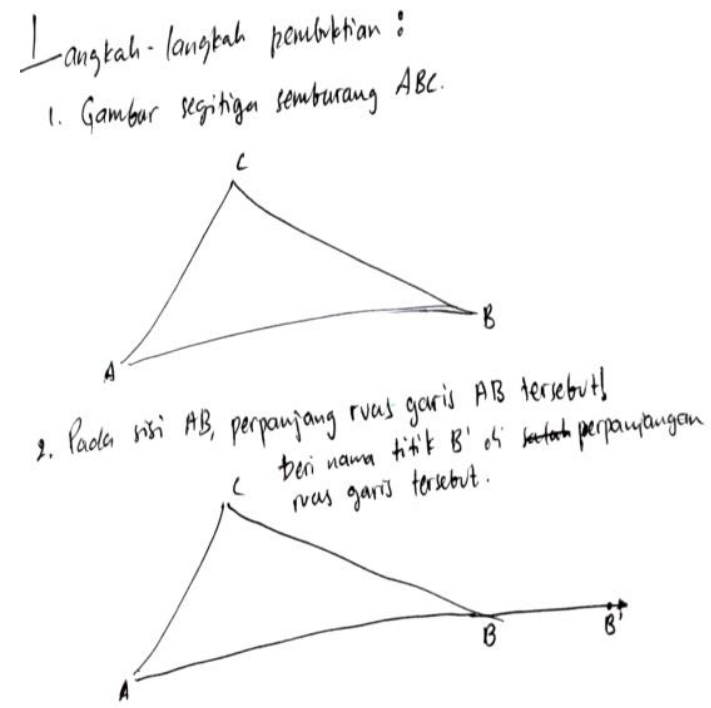

Gambar 3. Jawaban tertulis $\mathrm{S}_{2}$ dalam menggambar segitiga.

\section{c. Memahami masalah matematika yang diterapkan melalui analisis dan sintesis pembuktian}

Pada Gambar 4 dan transkrip wawancara $S_{2.7}$ di atas terlihat bahwa $S_{2}$ membuktikan teorema segitiga tersebut dengan memperpanjang salah satu sisi pada segitiga $A B C$ tersebut (sisi $A B$ ) lalu membuat garis lain yang sejajar dengan garis AC melalui titik B. Langkah-langkah pembuktian yang dilakukan $\mathrm{S}_{2}$ sistematis dan pembuktian teoremanya tepat. Jadi berdasarkan pedoman penskoran tes berpikir kritis untuk indikator ketiga yaitu peserta didik mampu memahami masalah matematika yang diterapkan melalui analisis dan sintesis pembuktian matematika adalah mampu membuktikan teorema pada masalah dengan cara yang benar, sistematis dan jawabannya tepat dengan memperoleh skor 4 (empat). Adapun jawaban tertulis $\mathrm{S}_{2}$ dalam membuktikan teorema disajikan pada Gambar 4.

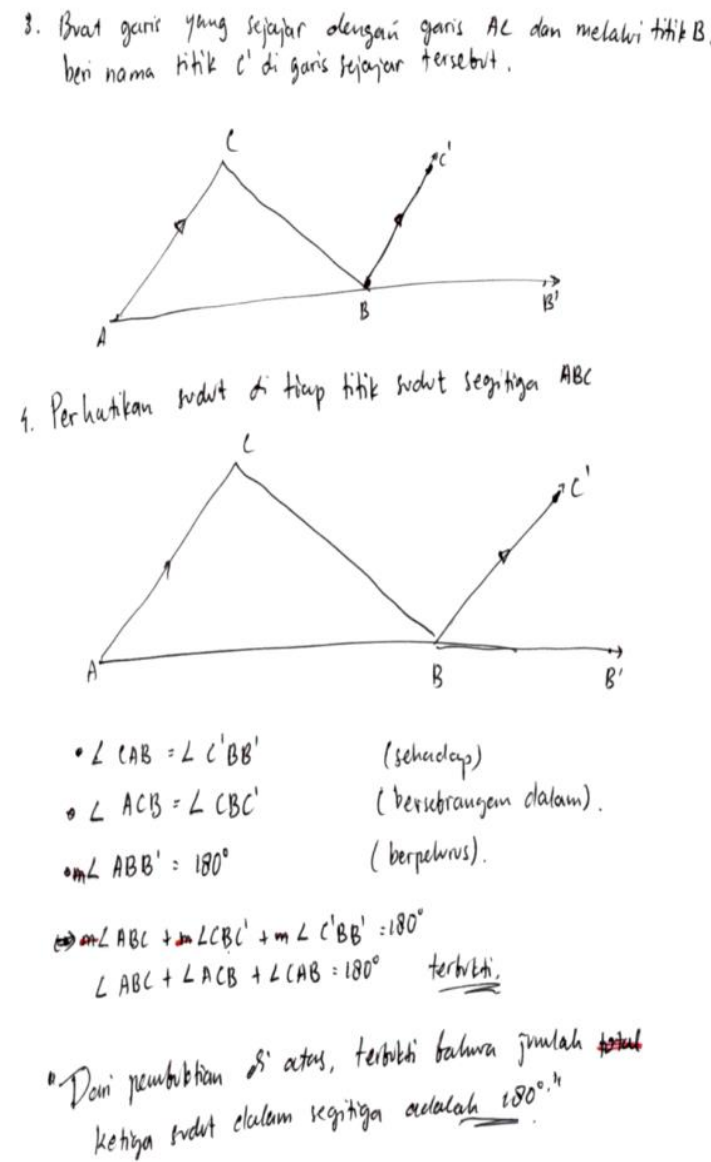

Gambar 4. Jawaban tertulis $S_{2}$ dalam membuktikan teorema geometri.

\section{d. Menganalisis bagaimana seluruh bagian dalam sistem matematika saling berinteraksi}

Pada jawaban tertulis $S_{2}$ tidak melakukan pengecekan kembali. Akan tetapi pada hasil wawancara $S_{2.20}$ tampak bahwa subjek $\mathrm{S}_{2}$ menjelaskan cara yang dilakukan pada pengecekan pembuktian adalah dengan melihat langkah jawabannya pada point 4, yaitu memperhatikan sudut di tiap titik sudut segitiga ABC dan gambar yang diketahui dan selanjutnya menarik kesimpulan bahwa jumlah sudut pada segitiga sama dengan $180^{\circ}$. Jadi berdasarkan pedoman penskoran tes berpikir kritis untuk indikator keempat 
yaitu peserta didik mampu menganalisis bagaimana seluruh bagian dalam sistem matematika saling berinteraksi adalah membuktikan teorema dan melakukan pengecekan kembali sebagai sistem matematika yang saling berinteraksi namun pengecekannya tidak lengkap dan tidak sistematis dengan perolehan skor 2 (dua). Adapun transkrip wawancara untuk indikator keempat sebagai berikut:

$P_{2.20}$ : Jadi terbukti teorema, kemudian apakah Anda melakukan pengecekan?

$S_{2.20}$ : Saya melihatnya dari point 4 nya seperti ini "perhatikan sudut di tiap titik sudut segitiga ABC dan gambar diketahui informasi seperti ini dan saya tarik kesimpulan bahwa jumlah sudut pada segitiga sama dengan 180 derajat.

Berdasarkan deskripsi dan analisis data di atas, dapat disimpulkan skor berpikir kritis $S_{2}$ seperti pada Tabel 5.

Tabel 5. Skor berpikir kritis $S_{2}$.

\begin{tabular}{|c|c|c|}
\hline No & $\begin{array}{c}\text { Aspek Penilaian } \\
\text { Berpikir Kritis }\end{array}$ & Skor \\
\hline 1. & $\begin{array}{l}\text { Menuliskan dan atau } \\
\text { menyebutkan apa yang } \\
\text { dibuktikan pada masalah } \\
\text { tersebut dengan tepat }\end{array}$ & 2 \\
\hline 2. & $\begin{array}{l}\text { Menggambar segitiga dengan } \\
\text { benar dan simbol-simbol } \\
\text { matematika yang ditulis } \\
\text { sudah tepat semua. }\end{array}$ & 4 \\
\hline 3. & $\begin{array}{l}\text { Membuktikan teorema pada } \\
\text { masalah dengan cara yang } \\
\text { benar, sistematis } \\
\text { (menuliskan apa yang } \\
\text { diketahui, ditanya dan } \\
\text { jawaban) serta jawabannya } \\
\text { benar. }\end{array}$ & 4 \\
\hline 4. & $\begin{array}{l}\text { Membuktikan teorema dan } \\
\text { melakukan pengecekan } \\
\text { kembali sebagai sistem } \\
\text { matematika yang saling } \\
\text { berinteraksi namun masih } \\
\text { ada sedikit yang salah dalam } \\
\text { pengecekan jawaban }\end{array}$ & 2 \\
\hline & Total & 12 \\
\hline
\end{tabular}

Berdasarkan pada Tabel 5 diperoleh bahwa total skor pada aspek penilaian berpikir kritis sebesar 12. Skor total ini jika dikategorikan sesuai dengan Tabel 3 maka termasuk kategori "sangat baik". Jadi dapat disimpulkan bahwa berpikir kritis $\mathrm{S}_{2}$ termasuk kategori sangat baik.

\section{Berpikir Kritis Subjek $S_{3}$}

a. Mencari struktur logis dalam mengatasi tantangan matematika

Apabila melihat jawaban tertulis $S_{3}$, tampak bahwa $S_{3}$ tidak menuliskan apa yang diketahui dan apa yang ditanyakan/apa yang akan dibuktikan. Akan tetapi pada hasil wawancara $S_{3.1}$, sampai $S_{3.3}, S_{3}$ mampu menyebutkan informasi/apa yang diketahui dan apa yang akan dibuktikan dengan tepat. $\mathrm{S}_{3}$ menyebutkan informasi yang ada pada soal itu adalah diketahui ada 3 sudut pada segitiga, dan menyebutkan apa yang akan dibuktikannya yaitu jumlah ketiga sudut tersebut sama dengan 180 derajat. Jadi berdasarkan pedoman penskoran tes berpikir kritis maka dapat disimpulkan bahwa skor yang diperoleh $\mathrm{S}_{3}$ untuk indikator pertama yaitu mencari struktur logis dalam mengatasi matematika adalah menyebutkan apa yang diketahui dan apa yang ditanyakan dari soal namun sebagian benar dan sebagian salah dengan perolehan skor 4 (empat). Transkrip wawancara $\mathrm{S}_{3}$ sebagai berikut:

$S_{3.1}$ : Kita harus membuktikan bahwa jumlah sudut pada segitiga itu sama dengan 180 derajat.

$P_{3.2}$ : Yang kedua apa yang ditanyakan pada soal tersebut?

$S_{3.2}$ : Yang ditanyakan buktikan bahwa jumlah sudut pada segitiga sama dengan 180 derajat.

$P_{3.3}$ : Oke, pertanyaan saya yang pertama informasi dan kedua apa yang ditanyakan? Berarti itu 2 jawaban yang berbeda loh ya tapi jawabannya kok sama. Harusnya pertanyaan saya yang pertama itu informasi itu berarti ketika 
DOI: https://doi.org/10.24127/ajpm.v9i1.2668

Anda membuktikan ini apa yang Ada dalam soal ini yang diketahui. Yang diketahui apa?

$S_{3.3}$ : Ketiga sudut pada segitiga

b. Menggambar segitiga dengan benar dan simbol-simbol matematika yang ditulis sudah tepat semua.

Pada Gambar 5 dan transkrip wawancara $S_{3.5}$ terlihat bahwa $\mathrm{S}_{3}$ menggambarkan dua garis yang sejajar pada suatu bidang $G$ lalu menggambar dua garis yang saling berpotongan dengan dua garis sebelumnya sehingga terbentuk suatu segitiga dengan benar dan simbol-simbol matematika yang ditulis sudah tepat semua. Jadi berdasarkan pedoman penskoran tes berpikir kritis untuk indikator kedua yaitu peserta didik mampu mengidentifikasi dan mengajukan pertanyaan penting tentang matematika dan terlibat dalam menganalisis jawabannya masing-masing adalah mampu menggambarkan segitiga dengan simbol-simbol matematikanya dengan tepat yang memperoleh skor 4 (empat). Adapun jawaban tertulis subjek $\mathrm{S}_{3}$ pada Gambar 5 .

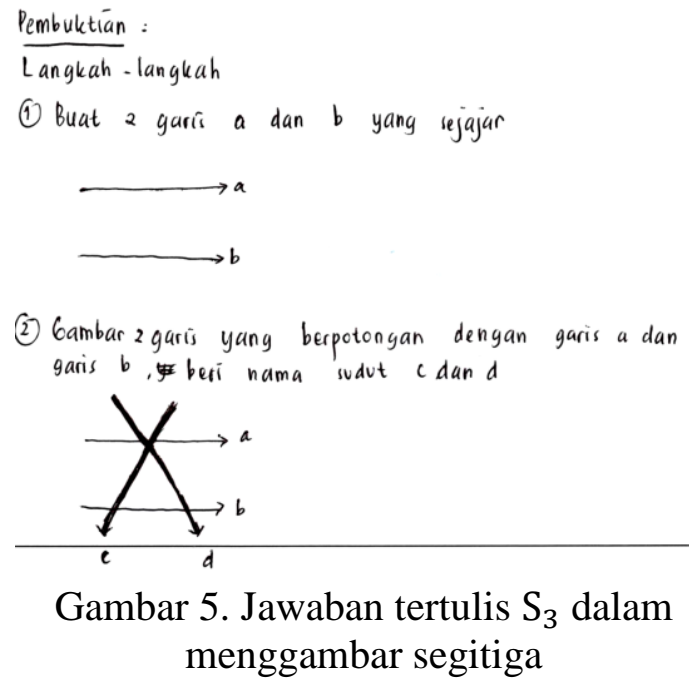

Gambar 5. Jawaban tertulis $S_{3}$ dalam menggambar segitiga

Sedangkan transkrip wawancara $\mathrm{S}_{3}$ sebagai berikut:

$S_{3.5}$ : Yaitu dengan menggunakan dua garis bidang $\mathrm{G}$ yang sejajar, kemudian dari sini, gambar 2 garis yang berpotongan dengan garis a dan garis $b$ kemudian beri sudut, beri nama garisnya yaitu garis c dan garis d.

\section{c. Memahami masalah matematika yang diterapkan melalui analisis dan sintesis pembuktian}

Pada Gambar 6 di bawah ini dan transkrip wawancara $S_{3.5}$ dan $S_{3.12}$ terlihat bahwa $S_{3}$ membuktikan teorema segitiga tersebut dengan mencari hubungan antar sudut yang dibentuk dari dua garis sejajar dan dua garis berpotongan. Langkah-langkah pembuktian yang dilakukan $\mathrm{S}_{3}$ sistematis dan pembuktian teoremanya tepat. Jadi berdasarkan pedoman penskoran berpikir kritis untuk indikator ketiga yaitu peserta didik mampu memahami masalah matematika yang diterapkan melalui analisis dan sintesis pembuktian matematika adalah mampu membuktikan teorema pada masalah dengan cara yang benar, sistematis dan jawabannya tepat dengan memperoleh skor 4 (empat). Adapun jawaban tertulis subjek $S_{3}$ pada Gambar 6.

(3) Dari gambar terrebut, terbentul $\angle 1, \angle 2, \angle 3, \angle 4$, dan $\angle 5$

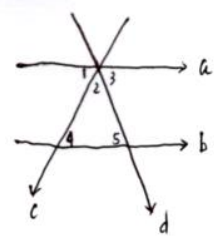

Buktí

1) $\angle 1+\angle 2+\angle 3=180^{\circ} \quad$ (membentuk sudut pelurus)

2) $L_{2}=L_{4} \quad$ (sudut-sudut beseberanyan dalam)

3) $L_{3}=L_{5} \quad$ (sudut - sudut berceberangan dalam)

4) $\angle 1+\angle 2+\angle 3=\angle 4+\angle 2+\angle 5$ (akibat langkah $1,2,3$ )

$\angle 4, \angle 2, \angle 5$ membentuk segitiga

Dari pembuktián diatas terbukti jumlah sudut segitiga besarnya adalah $180^{\circ}$

Gambar 6. Jawaban tertulis $S_{3}$ dalam membuktikan teorema geometri 
Sedangkan transkrip wawancara $\mathrm{S}_{3}$ adalah sebagai berikut:

$P_{3.12}$ : Coba jelaskan pembuktiannya ini?

$S_{3.12}$ : Sudut 1 , sudut 2 dan sudut 3 ini kan membentuk sudut pelurus, sudut pelurus itu kan besarnya 180 derajat. Kemudian sudut 2, sudut 4 ini kan termasuk sudutsudut yang berseberangan dalam, kemudian sudut 3 dan sudut 5 juga sudut-sudut yang berseberangan dalam. Nah dari sini, besar sudut 1 , sudut 2 dan sudut 3 sama dengan besar sudut 4, 2, 5 akibat langkah 1, 2 dan 3. Nah sudut 4, 2, 5 ini membentuk segitiga, sehingga terbukti sudut segitiga, sebenarnya adalah 180 derajat.

\section{d. Menganalisis bagaimana seluruh bagian dalam sistem matematika saling berinteraksi}

Pada jawaban tertulis $S_{3}$ dan transkrip wawancara $S_{3.13}$ tampak bahwa $S_{3}$ tidak melakukan pengecekan kembali. Jadi berdasarkan pedoman penskoran tes berpikir kritis untuk indikator keempat yaitu peserta didik mampu menganalisis bagaimana seluruh bagian dalam sistem matematika saling berinteraksi adalah membuktikan teorema dan melakukan pengecekan kembali sebagai sistem matematika yang saling berinteraksi namun pengecekannya tidak lengkap dan tidak sistematis dengan perolehan skor 0 (nol). Berikut hasil wawancara:

$P_{3.13}$ : Oke yang terakhir, setelah mendapatkan pembuktian teorema ini, apakah Anda melakukan pengecekan? Jika iya, pengecekan seperti apa yang Anda lakukan?

$S_{3.13}:$ Tidak

Berdasarkan deskripsi dan analisis data dapat disimpulkan skor berpikir kritis $S_{3}$ seperti pada Tabel 6 . Berdasarkan data pada Tabel 6 diperoleh bahwa total skor pada aspek penilaian berpikir kritis dan pemecahan masalah matematis sebesar 12. Skor total ini jika dikategorikan sesuai dengan Tabel 3 maka termasuk kategori "sangat baik". Jadi dapat disimpulkan bahwa kemampuan berpikir kritis dan pemecahan masalah $\mathrm{S}_{3}$ termasuk kategori sangat baik.

Tabel 6. Skor berpikir kritis $S_{3}$.

\begin{tabular}{|c|c|c|}
\hline No. & Aspek Penilaian & Skor \\
\hline 1. & $\begin{array}{l}\text { Menuliskan dan atau } \\
\text { menyebutkan apa yang } \\
\text { dibuktikan pada masalah } \\
\text { tersebut dengan tepat }\end{array}$ & 4 \\
\hline 2. & $\begin{array}{l}\text { Menggambar segitiga } \\
\text { dengan benar dan simbol- } \\
\text { simbol matematika yang } \\
\text { ditulis sudah tepat semua. }\end{array}$ & 4 \\
\hline 3. & $\begin{array}{l}\text { Membuktikan teorema } \\
\text { pada masalah dengan cara } \\
\text { yang benar, sistematis } \\
\text { (menuliskan apa yang } \\
\text { diketahui, ditanya dan } \\
\text { jawaban) serta jawabannya } \\
\text { benar. }\end{array}$ & 4 \\
\hline 4. & $\begin{array}{l}\text { Membuktikan teorema dan } \\
\text { melakukan pengecekan } \\
\text { kembali sebagai sistem } \\
\text { matematika yang saling } \\
\text { berinteraksi namun masih } \\
\text { ada sedikit yang salah } \\
\text { dalam pengecekan jawaban }\end{array}$ & 0 \\
\hline & Total & 12 \\
\hline
\end{tabular}

Berpikir kritis adalah proses yang berpusat atau bermuara pada pembuatan dan penarikan kesimpulan atau keputusan yang logis tentang tindakan apa yang harus dilakukan dan apa yang harus dipercaya atau diyakini”" (Ikhsan, Munzir, \& Fitria, 2017, hal. 235). Hasil paparan data dan analisis data berpikir kritis calon guru Pendidikan Matematika yang mengikuti PPL (Praktik Pengalaman Lapangan) dalam membuktikan suatu teorema Geometri diperoleh bahwa kedua subjek dari tiga subjek hanya mampu menyebutkan apa yang akan dibuktikan pada teorema tersebut, sedangkan subjek ketiga mampu menyebutkan 
informasi yang ada pada teorema tersebut baik menyebutkan apa yang diketahui dan apa yang akan dibuktikan. Berdasarkan perolehan skor tersebut didapatkan bahwa pada indikator mencari struktur logis dalam mengatasi tantangan matematika pada kedua subjek termasuk kategori cukup, sedangkan untuk subjek ketiga termasuk kategori baik.

Ketiga subjek sangat mampu menggambar segitiga dengan benar dan simbol-simbol matematika yang ditulis sudah tepat semua. Hal ini terlihat bahwa ketiga subjek menggambar segitiga dengan benar dan menuliskan simbol-simbol matematika dengan tepat juga. Berdasarkan skor perolehan diperoleh bahwa ketiga subjek termasuk kategori baik.

Selain itu, ketiga subjek juga sangat mampu memahami masalah matematika yang diterapkan melalui analisis dan sintesis pembuktian matematika. Hal ini terlihat bahwa ketiga subjek mampu membuktikan teorema geometri tersebut dengan benar, walaupun langkah-langkah pembuktiannya berbeda-beda. Berdasarkan pada perolehan skor, didapatkan bahwa ketiga subjek termasuk pada kategori baik.

Pada indikator menganalisis bagaimana seluruh bagian dalam sistem matematika saling berinteraksi tidak dilakukan oleh subjek ketiga. Hal ini hanya dilakukan pada kedua subjek saja walaupun dalam lembar pengerjaannya tidak tertulis dengan lengkap. Hal ini terlihat pada saat wawancara kedua subjek menjelaskan cara melakukan pengecekan kembali pembuktian teorema tersebut dengan cara yang berbeda-beda. Berdasarkan skor perolehan didapatkan bahwa kedua subjek termasuk kategori cukup, sedangkan subjek terakhir termasuk pada kategori kurang.

Berdasarkan skor perolehan pada masing-masing indikator kemampuan berpikir kritis matematis didapatkan bahwa total skor perolehan ketiga subjek sama yaitu mendapatkan total skor "12". Oleh karena itu, kategori pada ketiga subjek tersebut termasuk kategori sangat baik. Penelitian ini sesuai dengan penelitian terdahulu yang menyatakan bahwa ratarata keterampilan abad 21 pada mahasiswa pendidikan sebesar 3,80 yang termasuk kategori baik (Arnentis \& Asmawati, 2015). Wijaya, Sudjimat, \& Nyoto (2016) juga menyatakan bahwa berpikir kritis dan pemecahan masalah merupakan urutan pertama yang penting yang dibutuhkan di dunia kerja atau di dunia industri. Penelitian ini juga sejalan dengan penelitian Tican dan Deniz (2018) yang menyatakan bahwa calon guru siap untuk menerapkan keterampilan abad 21 dalam pembelajarannya khususnya keterampilan kognitif yaitu berpikir kritis.

Implikasi teoritis dari hasil penelitian ini yaitu dapat melatih kemampuan berpikir kritis calon guru dalam membuktikan suatu teorema pada matematika. Selain itu, dengan adanya penelitian ini dapat menjadikan calon guru termotivasi untuk meningkatkan kemampuan berpikir kritisnya dikarenakan berpikir kritis merupakan salah satu dari keterampilan abad 21. Selain itu, dampak dari hasil penelitian ini dapat dijadikan acuan bagi stakehoolder dalam hal ini sekolah atau madrasah tentang kesiapan calon guru matematika dalam mempersiapkan dirinya menghadapai tantangan abad 21 . 
DOI: https://doi.org/10.24127/ajpm.v9i1.2668

\section{KESIMPULAN DAN SARAN}

Sesuai dengan hasil paparan data dan temuan penelitian beserta pembahasan yang telah dipaparkan, didapatkan bahwa: (1) dua subjek dapat menuliskan dan atau menyebutkan apa yang dibuktikan pada masalah tersebut namun sebagian benar dan sebagian salah, hanya satu subjek yang menuliskan dengan benar dan lengkap, (2) semua subjek menggambarkan segitiga dengan benar dan simbolsimbol matematika yang ditulis tepat, (3) semua subjek dapat membuktikan teorema dengan cara benar dan sistematis, dan (4) dua subjek melakukan pengecekan kembali namun pengecekannya tidak lengkap dan tidak sistematis, sedangkan satu subjek tidak melakukan pengecekan pembuktian teorema. Jadi dapat disimpulkan bahwa berpikir kritis calon guru matematika pada penelitian ini dalam membuktikan teorema geometri termasuk kategori sangat baik.

Saran-saran yang dapat disampaikan berdasarkan hasil penelitian ini adalah bagi calon guru harus dapat meningkatkan kemampuan berpikir kritisnya untuk menghadapi abad 21. Sedangkan saran untuk peneliti selanjutnya yaitu keterampilan matematika yang sangat dipenting pada abad 21 ini tidak hanya berpikir kritis, oleh karena itu perlu diteliti lebih lanjut tentang keterampilan lain, seperti: berpikir kreatif, pemecahan masalah, komunikasi dan kolaborasi, dll yang sangat dibutuhkan peserta didik dalam menghadapi abad 21.

\section{DAFTAR PUSTAKA}

Alismail, H. A., \& McGuire, P. (2015). 21st Century Standards and Curriculum: Current Research and Practice. Journal of Education and Practice, 6 (6), 150-154.
Andriani, D. E. (2012). Program Peningkatan Mutu Guru Berbasis Kebutuhan. Manajemen Pendidikan, 23 (5), 395-402.

Arnentis, Y. F., \& Asmawati, W. (2015). Analisis keterampilan Abad 21 Mahasiswa Pendidikan Biologi FKIP Universitas Riau dalam Perkuliahan Teknik dan Manajemen Laboratorium. Jurnal Biogenesis, 12 (1), 47.

Basri, H., \& Purwanto, A. A. (2019). Investigating Critical Thinking Skill of Junior High Scholl in Solving Mathematical Problem. International Journal of Instruction, 12 (3), 745-758.

Bustami, Y., Suarsini, E., \& Ibrohim. (2019). Profil ketermapilan Berpikir Kritis Mahasiswa dalam Perkuliahan Zoologi. Jurnal Bioedukatika, 7 (1), 59-66.

Febrilia, B. R., Juliangkary, E., \& Korida, B. D. (2019). Analisis Proses Berpikir Siswa Dalam Memecahkan Soal Statistika. Aksioma: Jurnal Program Studi Pendidikan Matematika, 8 (3), 528-541.

Griffin, P., \& Care. (2015). Assessment and Teaching of 21st Century Skills: Methods and Approach. New York: Springer.

Hidayah, R., Salim, M., \& McGuire, P. (2017). Critical Thinking Skills: Konsep dan Indikator Penilaian. Jurnal Taman Cendekia, 1 (2), 127-133.

Ikhsan, M., Munzir, S., \& Fitria, L. (2017). Kemampuan Berpikir Kritis dan Metakognisi dalam Menyelesaikan Masalah Matematika Melalui Pendekatan Problem Solving. Aksioma: Jurnal Program Studi Pendidikan Matematika, 6 (2), 234-245. 
Karakoç, M. (2016). The Significance of Critical Thinking Ability in Terms of Education. International Journal of Humanities and Social Science, 6 (7), 81-84.

Khamidah, K., \& Suherman. (2016). Proses Berpikir Matematis Siswa dalam Menyelesaikan Masalah Matematika ditinjau dari kepribadian Keirsey. Al-Jabar: Jurnal Pendidikan Matematika, 7 (2), 231-248.

Lailiyah, S., Nusantara, T., Sa'dijah, C., \& Irawan, E. B. (2015). Proses Berpikir Versus Penalaran Matematika. Seminar Nasional Matematika dan Pendidikan Matematika (hal. 1019-1023). Surabaya: Universitas Negeri Surabaya.

Maharani, R., Rasiman, \& Rahmawati, N. D. (2019). Analisis Berpikir Kritis Siswa SMP dalam Menyelesaikan SOal Matematika Berbentuk Cerita. Imajiner: Jurnal Matematika dan Pendidikan Matematika, 1 (4), 6771.

Murawski, L. (2014). Critical Thinking in The Clasroom... And Beyond. Journal of Learning in Higher Education, 10 (1), 25-30.

Partnership21. (2011). 21st Century Skills Map Designed in Cooperation With The Nation's Math Educator. Washington DC: One Massachusetts Avenue NW Suite.

Prayitno, A. (2018). Characteristics of Students' Critical Thinking in Solving Mathematics Problems. The Online Journal of New Horizons in Education, 8 (1), 4655.

Rasiman. (2015). Leveling of Critical Thinking Abilities of Students of Mathematics Education in
Mathematical Problem Solving. IndoMS-JME (IndoMS-Journal of Mathematics Education), 6 (1), 40-52.

Santosa, C. A. (2013). Mengatasi Kesulitan Mahasiswa Ketika Melakukan Pembuktian Matematis Formal. Jurnal Pengajaran MIPA, 18 (2), 152160.

Suandi, B. (2017). Bukti Informal dalam Pembelajaran Matematika. Al-Jabar: Jurnal Pendidikan Matematika, 8 (1), 13-24.

Tican, C., \& Deniz, S. (2018). Preservice Teachers' Opinions about the Use of 21st Century Learner and 21st Century Teacher Skills. European Journal of Educational Research, 8 (1), 181-197.

Wijaya, Y. E., Sudjimat, D. A., \& Nyoto, A. (2016). Transformasi Pendidikan Abad 21 Sebagai Tuntutan Pengembangan Sumber Daya Manusia dan Global. Seminar Nasional Pendidikan Matematika, Vol. 1 (hal. 263278). Malang: Universitas Kanjuruhan Malang.

Yerizon. (2011). Peningkatan Kemampuan Pembuktian dan Kemandirian Belajar Matematik Mahasiswa Melalui Pendekatan M-Apos. Bandung: Disertasi Universitas Pendidikan Indonesia. 